\title{
Variability of coconut phenotype based on morphology and content of fatty acids in Asahan District, North Sumatra, Indonesia
}

\author{
LUTHFI AZIZ MAHMUD SIREGAR", RISMA DAMAYANTI, DIANA SOFIA HANAFIAH ${ }^{\text {vv }}$ \\ Department of Agro-technology, Faculty of Agriculture, Universitas Sumatra Utara. Jl. Prof A. Sofyan No. 3, Padang Bulan, Medan 20155, North \\ Sumatra, Indonesia. Tel./fax.: +62-61-8213236, •email: luthfi2004@yahoo.com; •`dedek.hanafiah@yahoo.co.id
}

Manuscript received: 20 April 2019. Revision accepted: 30 November 2019.

\begin{abstract}
Siregar LAM, Damayanti R, Hanafiah DS. 2019. Variability of coconut phenotype based on morphology and content of fatty acids in Asahan District, North Sumatra, Indonesia. Biodiversitas 20: 3413-3421. A study that aims to determine the diversity, relationship and fatty acid content in several coconut genotypes (Cocos nucifera L.) grown and cultivated in Asahan District of North Sumatra Province, Indonesia was investigated. The coconut was obtained from the Air Joman and Silau Laut subdistricts of Asahan District, between April and September 2017. This study used morphological observation method based on IPGRI (International Plant Genetic Resources Institute) coconut descriptor with purposive sampling technique. A total of 36 coconut genotypes have been collected and identified based on morphological characters and fatty acid content. Based on the morphological character, the genotype of G28 and G32 show the closest relationship with the dissimilarity value of 3.00 and the farthest relationship on the genotype of G40 and G43 with the dissimilarity value of 12.04. Based on the 10 main type fatty acids found in coconut oil, all genotypes have between 8 and 10 types of fatty acids, i.e. caprylic, capric, myristic, palmitic, stearic, oleic, linoleic and arachidic acid in the oil. The average amount of fatty acid contained in coconut oil obtained generally in other coconut oil. Genotype of G5 has the highest content of lauric acid and has 12.1 $\mathrm{mm}$ thick flesh, but only 8 types of fatty acid composition are present in the oil.
\end{abstract}

Keywords: Asahan, Cocos nucifera, fatty acid, genotype, morphology

\section{INTRODUCTION}

Indonesia has the largest coconut (Cocos nucifera L.) plantation in the world, with an area of 3.86 million ha or $31.2 \%$ of the world's total area of \pm 12 million ha. Most of the total area of coconut plantations in Indonesia are community plantations (98\%) and the rest are state and private plantations (Dekindo 2014). The spreading of coconut areas in Indonesia is Sumatra (34.5\%), Java $(23.2 \%)$, Sulawesi $(19.6 \%)$, Bali, West Nusa Tenggara and East Nusa Tenggara (8\%), Kalimantan (7.5\%), and Maluku and Papua $(7.5 \%)$. The national coconut productivity reached 3.29 million tons per year (Directorate General of Plantation 2015).

Superior coconut varieties characterized by the characteristics of slow or short stem growth, rapid and high fruit production are much needed for plant materials in an effort to increase the productivity of coconut (Mahayu and Novarianto 2014). In order to assembly, the superior varieties in coconut breeding program, the availability of genetic germplasm/sources is very important (Novarianto and Tampake 2007). One effort to produce superior coconut seed is by exploring, identifying, and selecting the plant germplasm collection in the experimental garden or in the coconut cultivation center areas (Santosa 2014).

Coconut oil extracted by dry and or wet extraction methods has its own characteristics compared to other vegetable oils. The main difference between coconut oil and other vegetable oils is the content of medium chain fatty acids present in coconut oil. Coconut oil contains medium chain fatty acids which can reach $61.93 \%$ (Karouw et al. 2013). The group of medium chain fatty acids is a fatty acid having 6-12 carbon atoms. The superiority of medium chain fatty acids in the digestive process compared to unsaturated fatty acids is the faster metabolism process resulting in the faster energy produced (Marten et al. 2006). Medium chain fatty acids have been used as a source of formula milk fats, food formulation ingredients for patients with impaired absorption, postoperative patients and the elderly in European and American countries. Lauric acid is the main middle-chain fatty acid in coconut oil that has efficacy as antiviral, antibacterial and antiprotozoa (Enig 1999). Although coconut oil contains saturated fatty acids, most of them are medium chain $(80 \%)$, and short chain $(10 \%)$ and only a few are long chain (palmitate, 5\%). Palmitate is atherogenic but the ratio of it level is much lower than lauric acid level which is not atherogenic. While the stearic acid (C-18) is not atherogenic because it will immediately be converted to oleic acid so that it is considered as a neutral acid (Silalahi and Nurbaya 2011).

Diversity analysis can be carried out using morphological, cytological, biochemical and molecular characterization. Initially, morphological markers were used for diversity analysis and are still in use. These were naturally occurring variants of a particular plant species. Later, cytological and biochemical differences occurring in the genotypes of a species started to be used in genetic diversity assessment (Bhandari et al. 2017). These analyses are carried out by raising germplasm lines, pure lines, 
improved varieties, etc. in a particular experimental design. This involves morphological characterization of different entries grown in the field as the morphological characteristics are the strongest determinants of the agronomic value and taxonomic classification of plants (Cholastova and Knotova (2012). Morphological evaluations are direct, inexpensive, easy and do not require expensive technology. However, the requirements of large tracts of land and human laborers over a period of time make it expensive. They suffer from the constraints of environmental-sensitivity and subjective characterization when compared to other methods.

Asahan District, North Sumatra Province, is a very famous area with coconut plantations and known as a source of good quality coconut. Several areas in Asahan District are the center of coconut plantation, i.e., Subdistrict of Air Joman, Silau Laut, Tanjung Balai, and Sungai Kepayang. However, many coconut plants have been cleared by their owners. This is because of the decrease of the yield, therefore many farmers sell their stems and convert their crops to other commodities that are considered more profitable. Therefore, the conservation efforts of the germplasm of coconut plants in Asahan District in particular and North Sumatra Province, in general, are very important. The objective of this study was to determine and evaluate coconut germplasm variability based on morphological characters, fatty acid content and the genetic relationships of several coconut genotypes from Asahan District, North Sumatra Province, Indonesia.

\section{MATERIALS AND METHODS}

\section{Study area}

The research was conducted from April to September 2017 in Air Joman and Silau Laut subdistricts of Asahan District, North Sumatra Province, Indonesia (Figure 1). The plant used in this research is the coconut (Cocos nucifera L.) plant owned by the farmers in the designated location, which is Air Joman Subdistrict and Silau Laut Subdistrict, Asahan District.

In each subdistrict, three villages were taken as centers of coconut production in the area, namely Pasar Lembu Village, Punggulan Village and Banjar Village for Air Joman Subdistrict; and Bangun Sari Village, Silo Baru and Silo Lama Village for Silo Laut Subdistrict. In each village, three farmers who owned coconut plantations which were the main sources of income were used as samples, and each farmer was taken two plant samples, so that 36 plant samples were used for this study. The coconut trees used as samples are coconut plants that are cultivated by farmers and are routinely taken as a result.
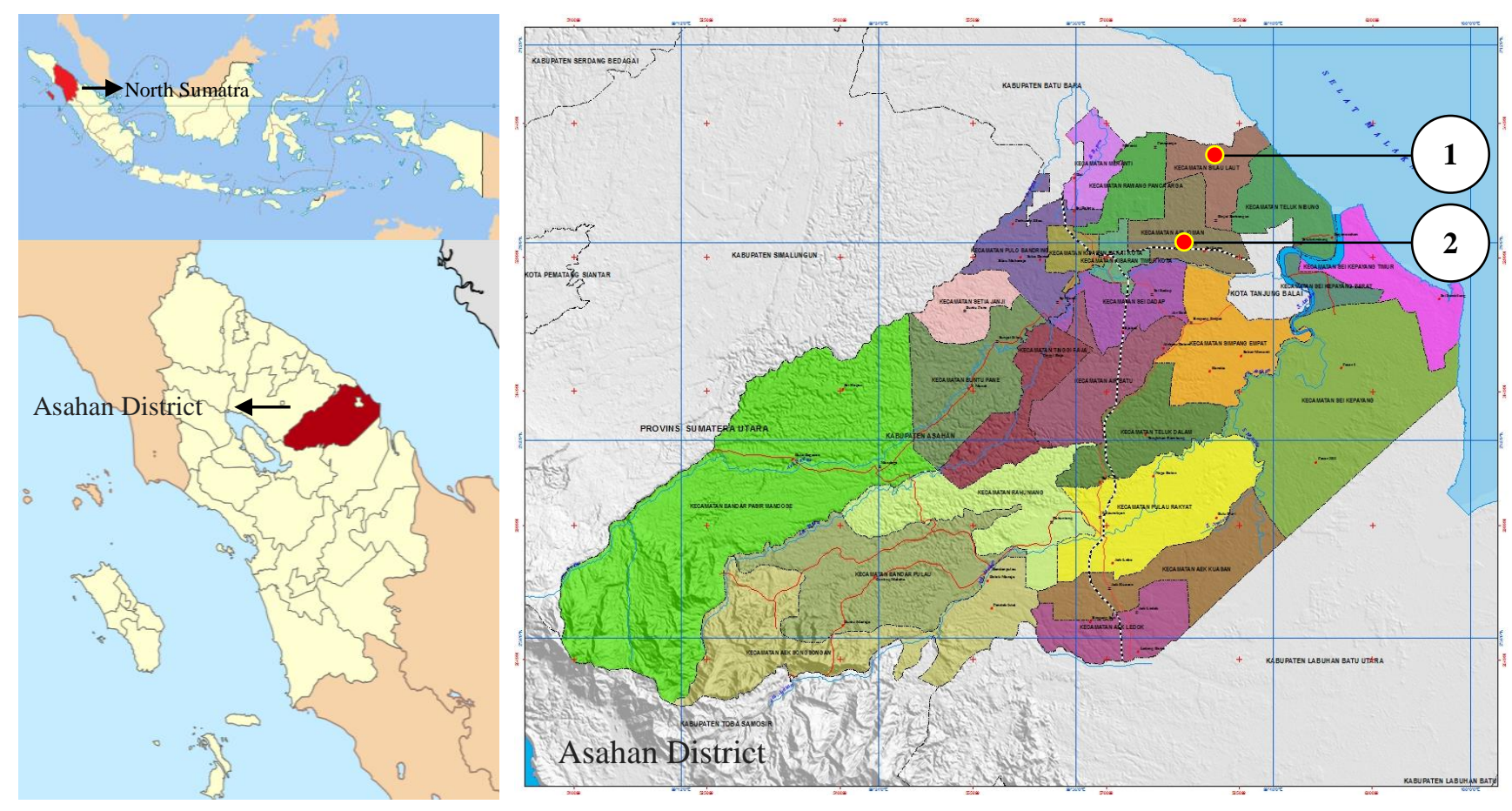

Figure 1. Research site area in Air Joman (1) and Silau Laut (2) Subdistricts of Asahan District, North Sumatra Province, Indonesia 


\section{Procedure}

This research is an exploratory research conducted by survey method in Air Joman and Silau Laut Subdistrict of Asahan District, North Sumatra. Data collection was obtained through observation of qualitative and quantitative character of plant morphological samples with a guide to the coconut descriptor manual of IPGRI (International Plant Genetic Resources Institute). The results of the quantitative character in this study were divided into three categories with divisions based on three quartile intervals tailored to the distribution of data on to all genotypes of coconut, thus showing a fixed distribution pattern (Syahruddin 2012). Determining the location of data distribution of the location distribution of this quartile is calculated according to Sudjana (2008) as follows:

$$
\begin{aligned}
& \text { Location } \mathrm{Ki}=\frac{\text { data to }(\mathrm{n}+1)}{4} \\
& \text { Location } \mathrm{Ki}=\text { location of quartiles to- } \mathrm{i}=1,2,3
\end{aligned}
$$

Parameter observations were performed by the coconut descriptors of IPGRI (1995), which consisted of observations: (i) Plant morphology; stem circumference at $20 \mathrm{~cm}$ from soil surface $(\mathrm{cm})$, stem circumference at $1.5 \mathrm{~m}$ from ground level $(\mathrm{cm})$, the height of tree $(\mathrm{m})$, number of bunches per tree. (ii) Leaf morphology; the length of the petiole $(\mathrm{cm})$, the thickness of the petiole $(\mathrm{cm})$, the width of the petiole $(\mathrm{cm})$, the length of the rachis $(\mathrm{cm})$, the number of leaflets, the length of the leaflets $(\mathrm{cm})$, the width of the leaflets $(\mathrm{mm})$. (iii) Flower morphology; the length of flower stalk $(\mathrm{cm})$, girth of flower stalk $(\mathrm{cm})$, number of spikelets with female flowers, number of spikelets without female flower, number of female flowers per rachilla, diameter of female flower (mm). (iv) Fruit morphology; number of fruits per tree, number of fruit per bunches, fruit weight $(\mathrm{g})$, coir weight $(\mathrm{g})$, shell weight $(\mathrm{g})$ fruit fresh weight $(\mathrm{g})$, and thick flesh (mm). (v) Quality of fruits; water content $(\%)$, fat content $(\%)$, and fatty acid content $(\%)$.

The characterization of tree, stem, leaf and flower morphology of habitus was carried out from one village to the next which was carried out on different days for each village. For leaf morphology characterization, the $14^{\text {th }}$ leaf sample was used. Sampling of flowers and fruit is done by climbing. Fruit samples are done on the same day by collecting the ripe fruit.

\section{Analysis of water content (\%), fat content (\%), and fatty acid content $(\%)$}

The determination of water content is done by oven method (AOAC, 1995). The grated coconut material is weighed $25 \mathrm{~g}$ in an aluminum cup which has been previously overburdened and weighed. Then the material was dried in an oven with an initial temperature of $50^{\circ} \mathrm{C}$ for 48 hours, then cooled in the desiccator for 15 minutes then weighed. After that, the material was reheated in an oven $60^{\circ}$ to $70^{\circ} \mathrm{C}$ (maximum), cooled back with a desiccator for 15 minutes then weighed. This treatment is repeated until a constant weight is obtained.
For the determination of fat content is done by extraction method using soxhlet (AOAC, 1995). Samples of $5 \mathrm{~g}$ which have been determined water content wrapped with filter paper, then placed in soxhlet extraction tool. The condenser is mounted on top of it and the fat pumpkin glass underneath. The hexane fat solvent is fed into a fat flask, then reflux for \pm 6 hours until the solvent falls back into a gray and clear-colored fat. The solvents present in the fat flask are distilled and recovered. Then the fat extraction flask is heated in an oven at $105^{\circ} \mathrm{C}$ until it reaches a fixed weight, and then cooled in a desiccator. Pumpkin glass and its fat are weighed. Each sample analyzed represents each accession number.

For quantitative analysis, the fatty acid content was carried out by gas chromatography device with standard method based on MPOB quality standard (Malaysia Palm Oil Board 2004). The required chemicals are as follows, nhexane, methanol, $\mathrm{NaOH} 0.5 \mathrm{M}, \mathrm{CH}_{3} \mathrm{COOH}$, distilled water, Fame Mix C8-C24 (Supelco®). The tools used are micropipette, Eppendorf tube, microsyringe $10 \mu \mathrm{L}$ (Hamilton Syringe ${ }^{\circledR}$ ), GC-2340 Supelco ${ }^{\circledR}$ with flame ionization detector (FID) at $185^{\circ} \mathrm{C}$ oven temperature condition, $240^{\circ} \mathrm{C}$ injector temperature, $240^{\circ} \mathrm{C}$ detector temperature, gas carrier $\mathrm{He} 0.8 \mathrm{~mL} / \mathrm{min}$ : capillary column SP2340 (60 x0.25mm, open tubular fused silica column coated).

\section{Data analysis}

The analysis of phenotypic data on quantitative characters is done to see the diversity present in the population. Comparative analysis of diversity was also done by looking at phenotypic comparisons with standard deviations of phenotype diversity.

The values of phenotypic diversity were calculated according to Steel and Torrie (1995) as follows:

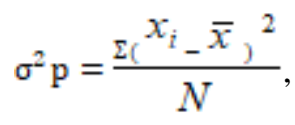

$\sigma^{2} \mathrm{p}=$ phenotypic variance;

$x_{i}=$ the value of the to-i sample

$\bar{x}=$ the average value of the to-i population

$\mathrm{N}=$ number of populations tested

Furthermore, the standard deviation of phenotype diversity is calculated by the formula:

$$
\begin{aligned}
& S d \sigma^{2} \mathrm{p}=\frac{\sqrt{\sigma^{2} \mathrm{p}}}{N}, \\
& \mathrm{Sd} \sigma^{2} \mathrm{p}=\text { standard deviation of phenotypic variance } \\
& \mathrm{N} \quad=\text { number of populations tested. }
\end{aligned}
$$

The criteria for assessment of the area and the narrowness of diversity were calculated based on Anderson and Bancroft (1952), namely: (i) Where, $\sigma^{2} \mathrm{p}>S d \sigma^{2} \mathrm{p}$ means that diversity is wide (varies), (ii) Where, $\sigma^{2} \mathrm{p}<S d \sigma^{2} \mathrm{p}$ means that the diversity is narrow (uniform). 
Standardized qualitative and quantitative data (plant morphology, leaf morphology, flower morphology, fruit morphology) with a total of 23 characters were processed using the Minitab 16 program with cluster analysis to determine the degree of relationships between accessions of each sample of each coconut plant in two subdistricts. Cluster analysis is used to visualize multivariate data (parameter data generated) from survey results. Cluster analysis produces a dendrogram that is used to assess patterns of diversity from data surveys.

\section{RESULTS AND DISCUSSION}

\section{Character of coconut phenotype}

Based on the observation of the morphological character of the coconut genotype in Asahan, there is diversity in the morphological characteristics of trees, leaves, flowers, and fruits. However, visual observations on the character of the stem growth pattern, the color of the leaf, the flowering type, the color of the female flower, the shape of the shell (the fruit without coir) almost have the characteristic similarity of the 36 identified coconut genotypes.

Based on the observation of the morphological character of the tree, 4 canopy forms were identified from the 36 identified coconut genotypes. In general, the shape of the coconut crown found is X 'silhouette' contained in G4, G9, G10, G12, G19, G26, G27, G28, G36, G37, G47, G48, G49, and G54. In addition, the pattern of coconut tree growth is generally curved. This is due to the presence of other plants that block the entry of the intensity of sunlight so that the growth of coconut trunks can be curved to follow the direction of the coming sun. Djaenudin et al. (2000) state that coconut plants require high intensity of sunlight. Plants that are under shade in a sheltered place are not good growth.

The coconut leaves have a leaf midrib with leaflets on the left and right sides. Based on the results of observations on the character of leaves morphology is known that in general the color of the child leaves is green, the color of the yellowish-green stalk, leaflets ranging from 100-150 $\mathrm{cm}$ long.

Coconut flowers are known by the term mayang or manggar. Identification result of floral morphological characters is known that the type of flowering of coconut, in general, is normal that the sheath has dried or even been separated from the manggar, the color of the flower stalk and the yellow female flowers, the color of male flowers yellow-greenish but there is one genotype with the color of the male flower is yellowish-orange is on G40, the number of female flowers in one essay and the diameter of the female flowers vary. Warisno (2003) states that the coconut flower is a rocky interest known as inflorescent or mayang or manggar (Java) and on the outside is covered by a spatial or sponge (spatha).

The morphology of coconuts generally varies depending on where it grows. Based on the identification of the morphological character of the fruit, it is known that coconut fruit, in general, is green, round fruit shape with fruit weight and thick of varied fruit flesh, round polar fruit shape, equatorial angular shape, shell shape (oblique fruit). According to Pandin (2009), coconut plants have a very diverse phenotypic. Diversity of fruit morphology is mainly on the color of fruit, shape, and size of fruit. Based on the results of the identification that has been done, it is known that there are various variations of coconut morphology in Asahan because the farmers do the coconut production generatively or using fruit, thus causing segregation and variation between genotypes. According to Pandin (2009) large coconut diversity caused by interest monoecious type and there are differences in the time and the beginning of the anthesis period of male flowers and receptive females.

The identification result of each genotype of coconut plant in Asahan has unique characteristic in certain genotypes so that the genotype can be used as a source of elderly in the propagation of coconut plant in the future, by combining some characters so it is expected to produce a new genotype with good character in terms of quality and quantity of fruit. Some genotypes that can be used as a source of elders with the advantage of several characters in each, namely genotype G4 has a thick and thick flesh character, G27 has a lot of fruit, and G35 has a unique color of fruit and shell (fruit without a coat) (in contrast to the color and shape of other fruit shells).

\section{Diversity of phenotype}

Based on the morphological character, 36 genotypes of coconut originating from Air Joman and SilauLaut subdistricts of Asahan District of North Sumatra, the criteria of phenotypic diversity were analyzed by comparison of diversity value with standard deviation can be seen in Table 1 .

The results of the phenotypic diversity analysis presented in Table 1 show that there are six narrow characters (uniform) that are on the thickness of the petiole, the width of the petiole, the width of the leaflets, the thickness of the flower stalk, the number of fruits per cluster, and the thickness of the fruit flesh. While the characters are wide (varying) that is on the character of the stem circumference at $20 \mathrm{~cm}$ from the ground surface, stem circumference at $1.5 \mathrm{~m}$ from the soil surface, tree height, the length of the petiole, the length of rachis, the number of leaflets, the length of the leaf, the long flower stalk, the number of spikelet with female flowers, the number of spikelet without the female flower, the number of female flowers in one essay, the diameter of the female flowers, the number of bunches per tree, the weight of the fruit, the weight of the coir, the weight of the shell, and the weight of the fruit flesh.

A number of coconut morphological characters show the vast diversity of phenotypes has been put forward by Tampake and Luntungan (2002), that the morphological diversity of 228 deep coconut trees and the coconut of Genjah collected 19 local coconut populations from several islands in Indonesia collected in the Pakuwon Experimental Garden, West Java shows the wide phenotypic variation in the stem circumference by $20 \mathrm{~cm}$ from the surface of the ground, the circumference of the rods at $1.5 \mathrm{~m}$ from the soil 
Table 1. Diversity of coconut phenotype in District of Asahan was based on comparison of diversity value with standard deviation

\begin{tabular}{|c|c|c|c|c|c|}
\hline \multirow{3}{*}{ Character } & \multicolumn{5}{|c|}{ Research location } \\
\hline & \multicolumn{5}{|c|}{ Air Joman and Silau Laut } \\
\hline & Average & $\sigma^{2} p$ & $S d \sigma^{2} p$ & $2 S d \sigma^{2} p$ & Criteria \\
\hline Stem circumference $20 \mathrm{~cm}$ from soil surface $(\mathrm{cm})$ & 80.72 & 713.92 & 26.72 & 53.44 & Wide \\
\hline Stem circumference $1.5 \mathrm{~m}$ from ground level $(\mathrm{cm})$ & 56.81 & 182.10 & 13.49 & 26.98 & Wide \\
\hline The height of tree (m) & 6.71 & 14.35 & 3.79 & 7.58 & Wide \\
\hline The length of the petiole $(\mathrm{cm})$ & 111.41 & 41.04 & 6.4 & 12.8 & Wide \\
\hline Thick of the petiole $(\mathrm{cm})$ & 2.85 & 0.18 & 0.41 & 0.82 & Narrow \\
\hline The width of the petiole $(\mathrm{cm})$ & 6.73 & 0.91 & 0.95 & 1.9 & Narrow \\
\hline Rachis length $(\mathrm{cm})$ & 338.06 & 1829.94 & 42.78 & 85.56 & Wide \\
\hline Number of leaflets & 98.83 & 96.19 & 9.81 & 19.62 & Wide \\
\hline Number of leaflets (cm) & 110 & 185.94 & 13.63 & 27.26 & Wide \\
\hline The width of the leaflets $(\mathrm{cm})$ & 4.91 & 0.47 & 0.68 & 1.36 & Narrow \\
\hline The length of the flower stalk $(\mathrm{cm})$ & 29.52 & 20.85 & 4.56 & 9.12 & Wide \\
\hline Girth of flower stalk $(\mathrm{cm})$ & 2.12 & 0.12 & 0.35 & 0.7 & Narrow \\
\hline Number of spikelet with female flowers & 20.47 & 85.58 & 9.25 & 18.5 & Wide \\
\hline Number of spikelet without a female flower & 12.97 & 82.30 & 9.07 & 18.14 & Wide \\
\hline Number of female flowers per rachilla & 22.92 & 129.41 & 11.38 & 22.76 & Wide \\
\hline Diameter of female flower (mm) & 24.18 & 14.13 & 3.76 & 7.52 & Wide \\
\hline Number of bunches per tree & 10.78 & 14.34 & 3.79 & 7.58 & Wide \\
\hline Number of fruits per bunches & 4.49 & 2.45 & 1.56 & 3.12 & Narrow \\
\hline Fruit weight $(\mathrm{g})$ & 1622.5 & 269657.6 & 519.29 & 1038.58 & Wide \\
\hline Coir weight $(\mathrm{g})$ & 838.06 & 113826.8 & 337.38 & 674.76 & Wide \\
\hline Shell weight (g) & 213.61 & 5156.4 & 71.8 & 143.6 & Wide \\
\hline Flesh weight $(\mathrm{g})(\mathrm{g})$ & 307.36 & 8921.51 & 94.45 & 188.9 & Wide \\
\hline Thick flesh (mm) & 10.35 & 2.82 & 1.68 & 3.36 & Narrow \\
\hline
\end{tabular}

Note: $\sigma^{2} p$ : phenotypic variance, $S d \sigma^{2} p$ : standard deviation of phenotypic variance

Table 2. The relationship of 36 coconut genotypes in Asahan District, North Sumatra, Indonesia based on dissimilarity matrix

\begin{tabular}{ccc}
\hline \multicolumn{2}{c}{ Relationships } & Dissimilarity value \\
\hline G28 & G32 & 3.000 \\
G22 & G48 & 3.606 \\
G4 & G9 & 3.742 \\
G3 & G52 & 3.873 \\
G31 & G54 & 3.873 \\
G41 & G48 & 4.000 \\
G41 & G49 & 4.000 \\
G3 & G13 & 4.123 \\
G14 & G20 & 4.123 \\
G22 & G49 & 4.359 \\
G51 & G47 & 4.472 \\
G17 & G36 & 5.568 \\
G18 & G35 & 7.810 \\
G2 & G9 & 7.937 \\
G5 & G12 & 8.718 \\
G26 & G38 & 8.775 \\
G30 & G37 & 9.274 \\
G4 & G13 & 10.677 \\
G32 & G40 & 10.724 \\
G40 & G47 & 10.770 \\
G31 & G43 & 10.817 \\
G7 & G19 & 10.863 \\
G10 & G40 & 10.954 \\
G23 & G40 & 11.091 \\
G40 & G44 & 11.180 \\
G27 & G40 & 11.832 \\
G40 & G43 & 12.042 \\
\hline & &
\end{tabular}

surface, the number of leaflets, the length of the leaflets, the length of the flower stalk, the number of spikelets with the female flower, the number of spikelets without the female flower, the number of flowers female in one essay. While the narrow character of the width of the petiole, thick petiole, wide child leaf, thick flower stalk.

\section{Relationship}

Based on the morphological characterization of 36 coconut genotypes obtained from two subdistricts in Asahan District, the values of relationships can be seen in Table 2. Based on the value of the dissimilarity matrix, the smaller the value of dissimilarity between variables, the relationships between the two variables is getting closer or the greater the level of similarity, and vice versa. So that it is known that the lowest level of dissimilarity or the closest relationships is G28 and G32 which is equal to 3,000 while the highest dissimilarity or the farthest relationships is in G40 and G43 which is equal to 12,042. To determine the level of relationships between accessions of each sample of each coconut plant in the two subdistricts, cluster analysis was used.

Based on multivariate data (parameters measured) survey results, the entire genotype of coconut can be grouped into four clusters. The pattern of diversity from the morphological data of 36 genotypes obtained from two subdistricts in Asahan can be seen in their relationship with dendrograms in Figure 2. There are four groups of 
relationships on the scale of the relation distance (Euclidean distance scale) 20 (twenty). The smaller the euclidean distance between the several objects analyzed, the closer the relation of the object and the more similarity the character possessed (Santoso 2002). Analysis of relationships based on morphological character of coconut genotype on a 20-degree scale indicates the presence of four groups of plant relationships. Group 1 consists of 21 genotype of coconut that is G2, G3, G10, G12, G13, G17, G31, G32, G36, G37, G38, G41, G44, G48, G49, G52 and G54 are put together by 1 character the same green leaf color.

The second group consists of 13 genotypes of coconut that are G4, G5, G7, G9, G14, G18, G20, G2, G26, G30, G43, G47 and G51 which are united by the same 2 characters of leaf color and flowering type. The third group consisted of only 1 genotype of coconut, G35. The special character that only the G35 possesses is a sharpened shell shape. The fourth group also consists of only 1 genotype of coconut that is G40. The special character that only G40 possesses is the color of the yellowish-orange flower. However, the G35 and G40 both have orange-colored fruits. Both of these genotypes have considerable euclidean distances when compared to thirty-four other genotypes. These characters cause the G35 and G40 to separate themselves from other groups and have an Euclidean spacing large enough.

The closest relationship or the lowest dissimilarity value was obtained from G28 and G32 from Bangun Sari village, Silau Laut subdistrict, which was 3,000 with 9 character difference from 36 characters which were identified as canopy shape, thickness of petiole, leaf width, rachis length, amount leaves, the length of the child leaves, the number of spikelet without the female flower, the weight of the shell and the weight of the fruit flesh.

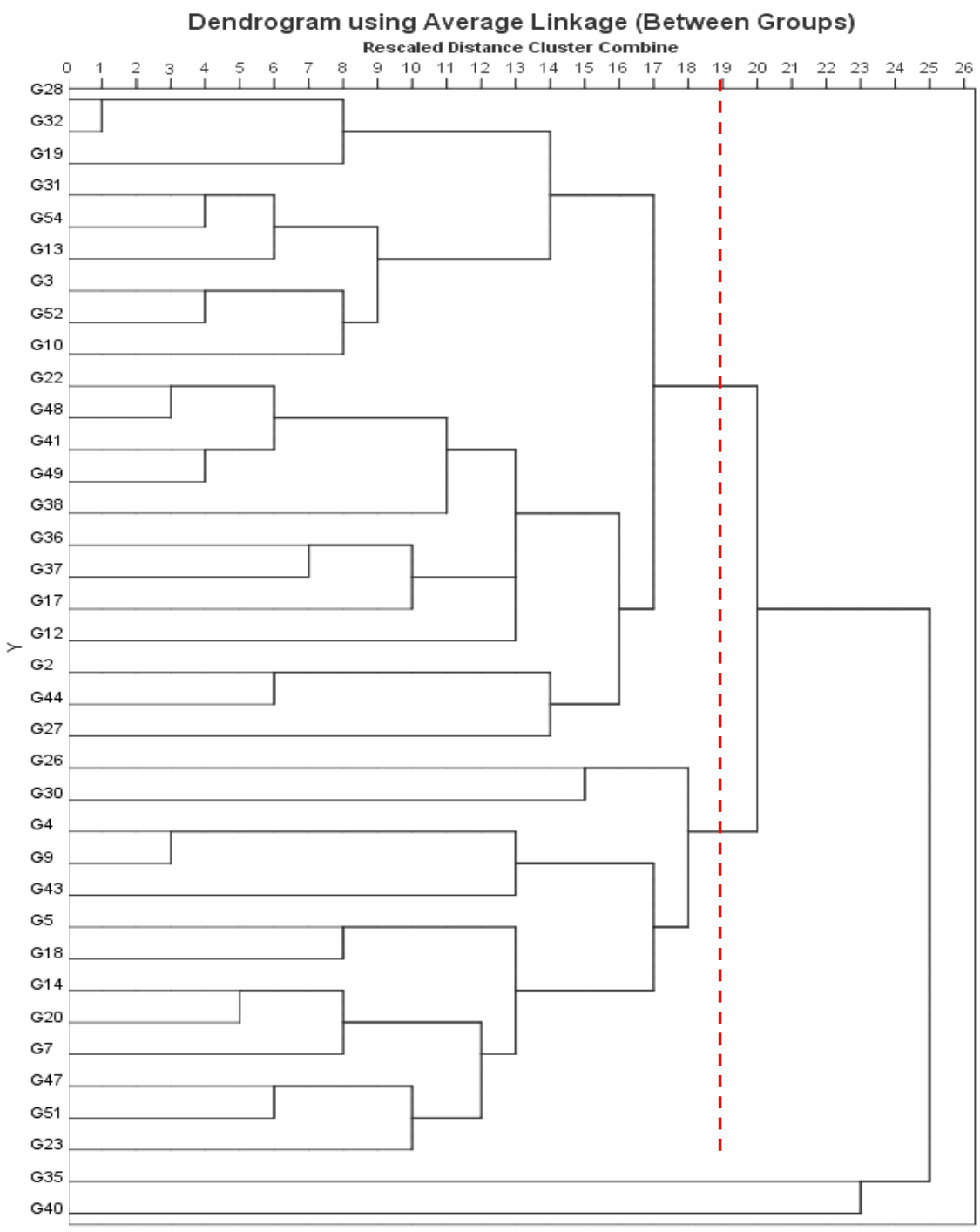

Figure 2. Dendogram grouping based on 23 quantitative and qualitative characters of 36 coconut genotypes obtained from Asahan District, North Sumatra, Indonesia 


\section{Water, fat and fatty acid content}

Based on Table 3, the highest water content was obtained from G2 accession samples (46.29\%) but with moderate fat content $(56.87 \%)$, while the lowest water content was obtained by G5 accession (15.79\%) with low fat content $(48.83 \%)$. The highest fat content was obtained by G41 accession (82.34\%) with a water content of $25.52 \%$. However, based on data on water content and fat content obtained, there was no consistent pattern of relationship between water content and fat content produced from each sample.

Coconut oil is classified into lauric acid because the content of lauric acid is greatest when compared to other fatty acids. Based on lauric acid levels, the low water content in the G5 accession showed high lauric acid levels $(50.4 \%)$, but the high water content in G2 turned out to show high lauric acid levels as well (48.1\%). This shows that the levels of fatty acids (such as lauric acid) in each accession are not always determined by water content, but also influenced by genetic factors that express the production of each fat content and fatty acid levels in each genotype.

Based on fat content, G3 accession showed the lowest fat content and followed by its lauric acid level included in the low category $(43.2 \%)$. Meanwhile, the highest fat content in G41 $(82.34 \%)$ turned out to show high lauric acid levels as well $(47.3 \%)$. This is much related to the process of forming lauric acid itself, coconut oil is an ester of glycerol and fatty acids.

Based on the results of coconut meat biomass extract derived from 36 accessions obtained from Air Joman Subdistrict and Silau Laut Subdistrict, Asahan District obtained oil and water content as in Table 3. Based on analysis of gas chromatograms, the composition and fatty acid content obtained on 36 accessions of coconut fruit can be seen in Table 3. Fatty acid analysis results presented in the table shows that fatty acids contained in coconut meat is saturated fatty acids and unsaturated fatty acids. The saturated fatty acids consist of caprylic acid $\left(\mathrm{C}_{7} \mathrm{H}_{15} \mathrm{COOH}\right)$, capric acid $\left(\mathrm{C}_{9} \mathrm{H}_{19} \mathrm{COOH}\right)$, lauric acid $\left(\mathrm{C}_{11} \mathrm{H}_{23} \mathrm{COOH}\right)$, myristic acid $\left(\mathrm{C}_{13} \mathrm{H}_{27} \mathrm{COOH}\right)$, palmitic acid $\left(\mathrm{C}_{15} \mathrm{H}_{31} \mathrm{COOH}\right)$ and stearic acid $\left(\mathrm{C}_{17} \mathrm{H}_{35} \mathrm{COOH}\right)$ saturated consisting of oleic acid $\left(\mathrm{C}_{17} \mathrm{H}_{33} \mathrm{COOH}\right)$ and linoleic acid $\left(\mathrm{C}_{17} \mathrm{H}_{31} \mathrm{COOH}\right)$. In addition, it can be detected in 26 genotypes of linolenic fatty acid $\left(\mathrm{C}_{17} \mathrm{H}_{29} \mathrm{COOH}\right)$ concentration at $0.1-0.3 \%$ and arachidic fatty acids $\left(\mathrm{C}_{19} \mathrm{H}_{39} \mathrm{COOH}\right)$ in 28 genotypes of coconut with low including $0.1-0.4 \%$.

Based on GC analysis, the dominant fatty acid component in 36 samples of coconut oil analyzed was lauric acid (C12:0) with the highest concentration found in G5 from PasarLembu village, Air Joman subdistrict at $50.4 \%$ while the lowest in G17 originating from Punggulan and G19 villages from Banjar village, Air Joman subdistrict with $35.6 \%$. In accordance with Nevin and Rajamohan (2006) studies that reported that the coconut oil analysis in the Kerala region of India contains $45.51 \%$ lauric acid and is the most dominant fatty acid. The results of fatty acid profile analysis of commercial coconut oil samples sold in Malaysia and Indonesia by Marina et al.
(2009) showed that the samples contained the most lauric acid ranging from 46.64 to $48.03 \%$, followed by myristic acid (C14:0) 16.23-18.90\%. The same study by Karouw et al. (2013) stated that the results of the analysis of oil on Dalam Mapanget coconut fruit age 11-12 months obtained from Kima Atas Experimental Garden, Manado, North Sulawesi had good quality and medium-chain fatty acids were $61.93 \%$ which is dominated by lauric acid around $48.24 \%$.

When viewed from the standardization issued by APCC (Asian and Pacific Coconut Community) that lauric acid content should be between $43-53 \%$, then from the analysis that has been done there are 30 samples of coconut oil that meet the requirements, among others: G2, G3, G4, G5, G7, G10, G12, G18, G20, G22, G23, G26, G27, G28, G30, G31, G32, G35, G36, G37, G38, G40, G41, G43, G44, G47, G48, G49, G51 and G52. This shows that $83.33 \%$ of all genotypes obtained from two subdistricts in Asahan District, North Sumatra, produce coconuts with lauric fatty acid content that relatively meets international standards.

Table 3. Water content and fat content for 36 accessions of coconuts collected from Air Joman and Silau Laut Subdistricts, Asahan District, North Sumatra, Indonesia

\begin{tabular}{ccc}
\hline Accesion & Water content $(\boldsymbol{\%})$ & Fat content $(\boldsymbol{\%})$ \\
\hline G2 & 46.29 & 56.87 \\
G3 & 28.27 & 15.22 \\
G4 & 24.71 & 56.37 \\
G5 & 15.79 & 48.83 \\
G7 & 31.87 & 53.99 \\
G9 & 24.74 & 24.28 \\
G10 & 20.83 & 79.15 \\
G12 & 26.46 & 63.26 \\
G13 & 38.15 & 68.58 \\
G14 & 33.52 & 67.64 \\
G17 & 32.59 & 71.32 \\
G18 & 23.71 & 62.65 \\
G19 & 27.78 & 58.50 \\
G20 & 26.98 & 70.90 \\
G22 & 24.14 & 52.18 \\
G23 & 25.82 & 68.76 \\
G26 & 35.02 & 68.35 \\
G27 & 26.34 & 67.21 \\
G28 & 21.54 & 69.96 \\
G30 & 25.55 & 62.94 \\
G31 & 62.45 \\
G32 & 35.74 & 75.26 \\
G35 & 32.00 & 63.32 \\
G36 & 19.47 & 65.64 \\
G37 & 25.00 & 25.63 \\
G38 & 38.60 & 53.86 \\
G40 & 23.05 & 57.06 \\
G41 & 82.34 \\
G43 & 39.72 & 64.63 \\
G44 & 25.52 & 60.18 \\
G47 & 21.34 & 76.96 \\
G48 & 29.75 & 38.65 \\
G49 & 19.12 & 66.18 \\
G51 & 84.98 \\
G52 & 27.98 & 28.43 \\
G54 & 21.91 & 49.90 \\
\hline & 22.26 & \\
\hline & 33.74 & \\
\hline
\end{tabular}


Table 4. Composition and fatty acid content of 36 accessions of coconut fruits which were collected from Air Joman and SilauLaut Subdistrict, Asahan District, North Sumatra, Indonesia

\begin{tabular}{|c|c|c|c|c|c|c|c|c|c|c|}
\hline \multirow{2}{*}{ Accession } & \multicolumn{10}{|c|}{ Fatty acid content (\%) } \\
\hline & (C8:0) & (C10:0) & (C12:0) & (C14:0) & (C16:0) & (C18:0) & (C18:1) & (C18:2) & (C18:3) & (C20:0) \\
\hline G2 & 10.2 & 6.0 & 48.1 & 18.1 & 7.1 & 2.8 & 5.7 & 1.9 & 0.1 & 0.1 \\
\hline G3 & 6.6 & 4.4 & 43.2 & 20.8 & 11.7 & 3.8 & 8.0 & 1.4 & 0.1 & - \\
\hline G4 & 8.1 & 5.0 & 43.7 & 19.3 & 11.8 & 3.3 & 7.3 & 1.4 & - & 0.1 \\
\hline G5 & 9.3 & 6.5 & 50.4 & 16.2 & 7.9 & 2.7 & 5.5 & 1.4 & - & - \\
\hline G7 & 7.1 & 5.2 & 46.4 & 18.5 & 10.5 & 3.6 & 7.1 & 1.5 & 0.1 & 0.1 \\
\hline G9 & 7.7 & 4.5 & 41.7 & 18.7 & 12.9 & 3.7 & 9.3 & 1.5 & - & - \\
\hline G10 & 7.0 & 4.7 & 47.2 & 19.5 & 10.1 & 3.1 & 6.7 & 1.7 & - & 0.1 \\
\hline G12 & 8.6 & 5.6 & 46.6 & 19.5 & 9.4 & 3.4 & 5.7 & 1.2 & 0.1 & 0.1 \\
\hline G13 & 5.9 & 4.5 & 38.2 & 18.3 & 10.1 & 3.5 & 6.7 & 1.4 & 0.1 & - \\
\hline G14 & 5.5 & 4.6 & 40.3 & 17.9 & 9.7 & 3.4 & 6.4 & 1.5 & 0.1 & - \\
\hline G17 & 6.7 & 3.5 & 35.6 & 17.0 & 9.4 & 3.3 & 6.4 & 1.4 & - & 0.1 \\
\hline G18 & 8.6 & 6.2 & 47.6 & 17.8 & 8.7 & 3.2 & 6.0 & 1.6 & 0.1 & 0.2 \\
\hline G19 & 8.7 & 5.7 & 35.6 & 22.7 & 12.3 & 4.1 & 9.0 & 1.6 & - & 0.1 \\
\hline $\mathrm{G} 20$ & 7.1 & 5.0 & 45.6 & 17.4 & 10.8 & 4.1 & 8.5 & 1.4 & - & 0.1 \\
\hline $\mathrm{G} 22$ & 9.0 & 6.1 & 49.5 & 17.1 & 8.8 & 2.7 & 5.3 & 1.3 & 0.1 & 0.1 \\
\hline $\mathrm{G} 23$ & 7.8 & 5.3 & 49.1 & 18.4 & 9.6 & 2.9 & 5.6 & 1.2 & 0.1 & 0.1 \\
\hline G26 & 7.5 & 5.5 & 47.5 & 17.7 & 9.8 & 3.2 & 6.7 & 1.8 & 0.1 & 0.1 \\
\hline $\mathrm{G} 27$ & 7.9 & 5.4 & 49.8 & 18.7 & 8.8 & 2.4 & 5.6 & 1.3 & 0.1 & - \\
\hline $\mathrm{G} 28$ & 5.9 & 4.1 & 43.3 & 20.3 & 11.8 & 3.6 & 8.9 & 1.8 & 0.1 & 0.2 \\
\hline G30 & 8.4 & 5.5 & 47.4 & 17.6 & 9.4 & 3.2 & 7.0 & 1.5 & - & 0.1 \\
\hline G31 & 6.8 & 4.8 & 44.1 & 20.0 & 11.2 & 3.7 & 7.7 & 1.6 & - & 0.1 \\
\hline $\mathrm{G} 32$ & 6.6 & 5.1 & 46.7 & 18.9 & 10.2 & 3.2 & 7.9 & 1.3 & 0.1 & 0.1 \\
\hline G35 & 7.4 & 5.1 & 47.1 & 19.2 & 9.7 & 3.3 & 6.6 & 1.3 & 0.1 & 0.2 \\
\hline G36 & 6.7 & 4.7 & 46.8 & 19.9 & 10.6 & 3.8 & 6.1 & 1.2 & 0.2 & 0.1 \\
\hline G37 & 7.9 & 5.5 & 47.9 & 18.8 & 8.9 & 2.9 & 6.2 & 1.3 & 0.3 & 0.3 \\
\hline G38 & 9.8 & 6.8 & 48.8 & 17.0 & 8.4 & 3.4 & 4.4 & 1.2 & 0.1 & 0.1 \\
\hline G40 & 6.9 & 5.1 & 48.3 & 18.2 & 9.6 & 2.7 & 7.1 & 1.7 & 0.1 & 0.3 \\
\hline G41 & 8.0 & 5.7 & 47.3 & 18.1 & 9.7 & 3.6 & 6.6 & 0.9 & 0.1 & - \\
\hline G43 & 10.0 & 6.7 & 49.3 & 16.6 & 7.8 & 3.2 & 4.9 & 1.0 & 0.3 & 0.2 \\
\hline G44 & 7.9 & 5.5 & 48.6 & 17.7 & 8.7 & 2.8 & 6.8 & 1.5 & 0.2 & 0.2 \\
\hline G47 & 5.7 & 4.5 & 44.9 & 19.0 & 12.6 & 3.4 & 7.9 & 1.4 & 0.1 & 0.4 \\
\hline G48 & 6.8 & 4.6 & 44.3 & 19.1 & 11.7 & 3.8 & 8.0 & 1.5 & 0.1 & 0.2 \\
\hline G49 & 6.9 & 4.8 & 45.6 & 19.5 & 10.8 & 3.5 & 7.3 & 1.4 & 0.1 & 0.1 \\
\hline G51 & 5.9 & 4.7 & 48.2 & 19.9 & 9.9 & 3.3 & 6.2 & 1.8 & 0.1 & 0.1 \\
\hline G52 & 7.2 & 3.8 & 45.9 & 16.5 & 12.1 & 3.1 & 9.6 & 1.7 & 0.1 & 0.1 \\
\hline G54 & 4.8 & 4.4 & 41.3 & 20.8 & 12.5 & 4.5 & 9.8 & 1.7 & 0.1 & - \\
\hline
\end{tabular}

Note: C8:0 : Caprylic acid, C10:0 : Capric acid, C12:0 : Lauric acid, C14:0 : Myristic acid, C16:0 : Palmitic acid, C18:0 : Stearic acid, C18:1 : Oleic acid, C18:2 : Linoleic acid, C18:3 : Linolenic acid, C20:0 : Arachidic acid

Based on evaluation of morphological character on 36 samples of coconut fruit and associated with fatty acid content contained therein obtained that in G5 with the highest lauric acid content has a character of flesh which is classified as thick that is $12,1 \mathrm{~mm}$. However, in the thickest character of the highest fruit meat found in G4 that is 13.7 $\mathrm{mm}$ has a lauric acid content of $43.7 \%$. This is because there are factors that influence fatty acid content of coconut flesh, among others coconut type and varieties, coconut age, climate, soil type and altitude. The increasing age of coconut fruit then the fatty acid content will increase and water content decreases. Bawalan (2005) which stated that the fatty acid content of coconut meat is influenced by several factors such as coconut type and variety, coconut age, climate, soil type and altitude. The land suitability class for coconut plantations is basically based on the horizon where the coconut plants will be planted, the physical properties of the soil, and the ability of the soil to retain water. The existence of water in the soil is the basis for the classification of land suitability for coconut trees because it affects the use of water, especially during drought. Available groundwater also affects the leaf area of coconut plants and water storage capacity in the stem which both affect the rate of plant transpiration. Differences in coconut varieties also have differences in plant water requirements which also affect the suitability of the land needed for coconut trees (Madurapperuma et al. 2009).

This study has collected and characterized 36 genotypes of coconut from Air Joman and SilauLaut Subdistrict of Asahan District, North Sumatra. The result of phenotypic diversity analysis shows that there are six narrow characters (uniform), i.e. visual observation on character of growth pattern of stem, flowering type, shell shape (fruit without coir); and thirty other characters have wide diversity of phenotypes. The closest phylogenetic relationship genotypes G28 and G32 are originated from Silau Laut Subdistrict, with the dissimilarity value of 3.00. 
While the furthest relation or the highest is obtained at genotype coming from subdistrict of Air Joman Subdistrict G40, and G43 from Silau Laut subdistrict, with the dissimilarity value of 12.04 . The identification result of 36 accessions of coconut in Asahan has a different and special character on some accessions. So it can be used as source in the development of coconut in the conventional field or as parents origin by combining some of these characters to preserve coconut crop, and also improve the yield and quality of coconut. The coconut genotype collected has 810 fatty acids in its oil. The average fatty acid content contained in coconut oil obtained is generally obtained in coconut oil. Genotype of G5 has the highest content of lauric acid and has $12.1 \mathrm{~mm}$ thick flesh, but only 8 types of fatty acid composition are present in the oil.

\section{ACKNOWLEDGEMENTS}

This research was conducted under TALENTA USU Research Contract, Basic Research Scheme of Fiscal Year 2017 with funding of Non-PNBP USU Year 2017. Contract Number: 287/UN5.2.3.1/PPM/KP-TALENTA USU/2017, dated May 30, 2017.

\section{REFERENCES}

Anderson RL, Bancroft TA. 1952. Statistical Theory in Research McGraw Hill Book Company, New York, USA.

AOAC. 1995. Official Methods of Analysis, ch. 3. Association of Official Analytical Chemists, Gaithersburg, MD..

Bawalan DD. 2005. A Technical Input to the Project Pilot Demonstration of Small-Scale Equipment for Production of Virgin Coconut Oil and Products in Thailand. Food and Agriculture Organization of the United Nations - Thailand Departement of Agriculture, Bangkok.

Bhandari HR, Bhanu AN, Srivastava K, Singh MN, Shreya, Hmenataranjan A. 2017. Assessment of genetic diversity in crop plants - An overview. Adv Plants Agric Res 7 (3): 00255. DOI: 10.15406/apar.2017.07.00255.

Cholastova T, Knotova D. 2012. Using morphological and microsatellite (SSR) markers to assess the genetic diversity in alfalfa (Medicago sativa L.). Intl J Biol 6 (9): 781-787.

Dekindo [Dewan Kelapa Indonesian]. 2014. Consult and coordinate for the development of the national oil palm industry in 2009 DewanKelapa Indonesia. www.dekindo.com/event/seminar. [Indonesian]
Directorate General of Plantation [Direktorat Jenderal Perkebunan]. 2015. Area and plantation production throughout Indonesia. www.ditjenbun.deptan.go.id/cigraph/index.php/viewstat/komoditiuta $\mathrm{ma} / 5$-Coconut. [Indonesian]

Djaenudin D, Marwan H, Subagyo H, Mulyani A, Suharta N. 2000. Kriteria Kesesuaian Lahan untuk Komoditas Pertanian. Pusat Penelitian Tanah dan Agroklimat, Bogor. [Indonesian]

Enig ME. 1999. Coconut: In Support of Good Health in the 21st Century. Paper presented on APPC'S XXXVI session and 30 Anniversary in Pohnpei, Federated States of Micronesia, 27-28 September 1999.

IPGRI. 1995. Descriptors of Coconut (Cocos nucifera L.). International Plant Genetic Resources Institute. Rome, Italy.

Karouw S, Suparmo, Hastuti P, Utami T. 2013. Synthesis of medium chain methyl esters from coconut oil by means of chemical methanolysis. Agritech 33 (2): 182-188.

Madurapperuma WS, de Costa WAJM, Sangakkara UR, Jayasekara C. 2009. Estimation of water use of mature coconut (Cocos nucifera L.) cultivars (CRIC 60 and CRIC 65) grown in the low country intermediate zone using the compensation heat pulse method (CHPM). J Nat Sci Found Sri Lanka 37 (3): 175-186.

Mahayu WM, Novarianto H. 2014. Characteristics of selfing coconut generation in Mapanget for selection of pollen source mother trees. Bul Palma 15 (1): 24-32. [Indonesian]

Marina AM, Che MYB, Nazimah SAH. 2009. Chemical properties of virgin coconut oil. J Am Oil Chem Soc 86: 301-307.

Marten B, Pfeuffer M, Schrezenmeir J. 2006. Medium-chain triglycerides: Review. Intl Dairy J 16: 1374-1382.

Nevin KG, Rajamohan T. 2006. Virgin coconut oil supplemented diet increases the antioxidant status in rats. Food Chem 99: 260-266.

Novarianto H, Tampake H. 2007. Development of PVT-based Coconut Seed Industry and In Situ Germplasm Conservation. Research Institute for Coconut and Other Palma Plants, Manado. [Indonesian]

Pandin DS. 2009. Breeding Depression in Four Generations of Closed Pollination of Coconut Plants in Mapanget No. 32 Based on Morphological Properties and Microsatellite Markers. [Thesis]. Institut Pertanian Bogor, Bogor. [Indonesian]

Santosa B. 2014. Status of breeding of coconut plants in supplying superior seeds in Indonesia. Perspektif 13 (2): 99-110. [Indonesian]

Santoso S. 2002. Multivariate Statistics SPSS Exercise Book. PT Elex Media Komputindo, Jakarta. [Indoensian]

Silalahi J. Nurbaya S. 2011. Composition, distribution and atherogenicity of fatty acid in coconut and palm oils. J Indones Med Assoc 61 (11): 453-457. [Indonesian].

Steel RGD, Torrie JH. 1995. Statistical Principles and Procedures. Bambang Sumantri's translation. PT Gramedia. Jakarta. [Indoensian]

Sudjana 2008. Statistics Method. PT Tarsit, Bandung. [Indonesian]

Syahruddin K. 2012. Diversity Analysis of Durian Genotypes (Durio zibethinus Murr.) using Morphological and Molecular Markers (ISSR). [Thesis]. Institut Pertanian Bogor, Bogor. [Indonesian]

Tampake H, Luntungan HT. 2002. Pendugaan parameter genetik dan korelasi antar sifat-sifat morfologi kelapa (Cocos nucifera Linn.). J Littri 8 (3): 97-102. [Indonesian]

Warisno. 2003. Cultivation of Genjah Coconut. Kanisius, Yogyakarta. [Indonesian] 